J. Lake Sci. (湖泊科学), 2018, 30(1): 79-90

DOI 10. 18307/2018. 0108

(c) 2018 by Journal of Lake Sciences

\title{
云南星云湖水质变化及其人文因素驱动力分析
}

\author{
郑田甜 ${ }^{1}$, 赵祖军 ${ }^{2}$, 赵筃青 ${ }^{1 * *}$, 顾泽贤 ${ }^{1}$, 普军伟 ${ }^{1}$, 卢飞飞 ${ }^{1}$ \\ ( 1 : 云南大学资源环境与地球科学学院,昆明 650500) \\ $(2:$ 云南省环境监测中心站, 昆明 650034$)$
}

\begin{abstract}
摘 要: 星云湖目前存在水污染加重、富营养化进程加快、水体功能受损等问题. 以星云湖为研究对象, 根据星云湖 20052015 年的水质数据、社会经济统计数据和遥感影像图,运用目视解译、叠加分析、污染足迹模型及主成分分析法, 分析了 星云湖流域近 10 年以来水质变化趋势、入湖河流污染物污染足迹及其人文因素驱动力. 结果表明: (1) 水质数据趋势表 明,从月变化看, 3 月份水质最好, 9 月份水质最差; 从年变化看, 2005-2015 年间, 2008 年水质状况最好, 2014 年的水质 状况最差,从 2008-2014 年水质持续变差,到 2015 年好转. (2) 2015 年有机物、氮和磷的污染足迹分别为 $583.26 、 705.88$ 和 $494.11 \mathrm{~km}^{2}$. 污染足迹前 4 位的人湖河流依次为: 大街河>东西大河东河>渔村河>东西大河西河, 占星云湖流域总污染 足迹的 $66.21 \%$. 污染程度大的大街河、东西大河和渔村河周边土地利用类型为水田、旱地和村庄. (3) 星云湖水质影响因 素第 1 主成分 (总人口、播种面积、农村人口、化肥使用量、农膜使用量、大牲畜存栏量) 与农村生活和农业面源污染有关; 第 2 主成分 (人均 GDP、第一产业产值、第二产业产值、第三产业产值) 与社会经济发展有关. 因此, 星云湖流域水质变化 的人文因素驱动力为农村生活和农业面源污染类和社会经济发展类, 其中第 1 主成分的贡献率是 $84.389 \%$, 农村生活和 农业面源污染是水质变化的主要驱动力.
\end{abstract}

关键词: 星云湖; 人湖河流;面源污染; 足迹;社会经济因素;高原湖泊

\section{Water quality change and humanities driving force in Lake Xingyun, Yunnan Province}

\author{
ZHENG Tiantian $^{1}$, ZHAO Zujun ${ }^{2}$, ZHAO Xiaoqing ${ }^{1 * *}$, GU Zexian ${ }^{1}$, PU Junwei ${ }^{1} \&$ LU Feifei ${ }^{1}$ \\ (1: College of Resource Environment and Earth Science, Yunnan University, Kunming 650500, P.R.China) \\ (2: Yunnan Environmental Monitoring Center Station, Kunming 650034, P.R. China)
}

\begin{abstract}
Lake Xingyun faces the problems of worsening water pollution, accelerating eutrophication and damaged function of water body. This paper employs visual interpretation, overlay analysis, pollution footprint model and principal component analysis to analyze water quality changes as well as the pollution footprint and humanities driving force of the pollutants in the lake and rivers based on water quality data, statistical data on the society and economy, as well as remote sensing images. The results show that the water quality at Lake Xingyun is best in March and worst in September. During the period from 2005 to 2015, the water quality was best in 2008 but worst in 2014. From 2008 to 2014, the water quality got worsening and then reversed since 2015. In 2015, the pollution footprint of organic matter, nitrogen and phosphorus pollution occupied 583.26, 705.88 and $494.11 \mathrm{~km}^{2}$, respectively. The top four rivers with the most pollution footprint for the pollutants in the lake and river are listed as Dajie River, Eastern River, Yucun River and Western River, accounted for $66.21 \%$ of the total pollution footprint in Lake Xingyun. The land use in the four rivers with the highest degree of pollution can be classified as the paddy field, dry land or village. The first principal component (total population, planting area, rural population, fertilizer use amount, plastic sheeting use amount, large livestock stock amount) influencing the water quality of Lake Xingyun is related to the rural life and agricultural pollution. The second principal component (per capita GDP, firstly industry output value, secondary industry output value, tertiary industry output value) is connected with the social and economic development. Hence, the humanities driving force for water quality changes in Lake Xingyun
\end{abstract}

* 玉溪地区三大湖泊 (抚仙湖、星云湖、杞麓湖) 遥感监测项目 (玮元-A2016191)、“第二批云岭学者培养” 项目 (C6153001) 和云南大学第八届研究生科研创新项目 (ynuy2016113) 联合资助. 2016-11-23 收稿; 2017-03-03 收修改稿. 郑田甜 (1994 ), 女, 硕士研究生; E-mail: 1971504997@ qq.com.

** 通信作者; E-mail: zhaoxq748@ sohu.com. 
can be classified as the rural life and agricultural pollution or social and economic development. The first principal component has a contribution rate of $84.389 \%$, which means that it is the major driving force for water quality changes.

Keywords: Lake Xingyun; inflow; non-point source pollution; footprint; social economic factors; plateau lakes

湖泊资源是社会经济发展的重要资源 ${ }^{[1]}$. 星云湖是云南省九大高原湖泊之一,具有工农业用水、调蓄、 防洪、旅游、水产养殖等功能. 由于湖泊换水周期长 ${ }^{[2]}$ 以及湖泊流域内工农业生产的发展、人口的快速增长, 使资源需求量迅速增加, 大量工农业及生活废污水排人湖泊, 使水体污染严重, 湖泊的生态环境遭到巨大破 坏, 有数据显示, 星云湖已经为富营养化湖泊 ${ }^{[3]}$.

国内关于星云湖水质变化的相关研究开始于 1963 年 ${ }^{[4]}$. 此后, Zhang 等 $^{[5]}$ 对星云湖湖泊沉积物进行研 究, 分析了流域气候变化和人类活动; Zhang 等 ${ }^{[6]}$ 同样研究了湖泊沉积物并依此重建了 20 世纪星云湖流域 气候变化和人类活动; 张洁等 ${ }^{[7]}$ 基于 MODIS 数据, 利用水质遥感监测的方法得到叶绿素 $\mathrm{a}$ 浓度、悬浮物浓度 和 MODIS 遥感数据空间和时间上的分布情况, 通过对它们进行回归关系分析, 得到适合星云湖水质的遥感 定量模型; 国外 Fukushima 等 ${ }^{[8]}$ 利用气象条件与水质的过去关系预测湖泊水质变化对气候变化的响应; 国内 秦洁等 ${ }^{[9]}$ 、张云鹰等 ${ }^{[10]}$ 分别从浮游植物、气候方面对星云湖的水质变化进行了分析. 综合国内外对星云湖 水质变化的研究, 大多数都集中在气候变化、降雨、湖泊沉积物、浮游植物等自然因素方面, 鲜有人类活动对 星云湖水质变化方面的研究.

近年来, 社会经济的快速发展导致流域污染负荷总量快速增加, 给星云湖的生态环境带来巨大压力, 原 本就十分突出的水环境问题进一步恶化, 水质明显下降, 制约了当地经济的发展 ${ }^{[11]}$. 因此了解星云湖水质 变化特征, 分析湖泊水质变化的人文因素驱动力, 可以为未来湖泊污染防治计划提供思路与方案, 对生态环 境保护、区域经济发展都具有重要意义. 本文在星云湖水质随时间变化分析基础上,研究水质变化过程中人 文因素所起的驱动作用; 并通过主成分分析方法, 提取主要的人文因子指标; 其次采用污染足迹模型与遥感 判读相结合, 呈现人湖河流的污染足迹与周围的土地利用类型的关系, 总结人类活动在研究期内对湖泊水

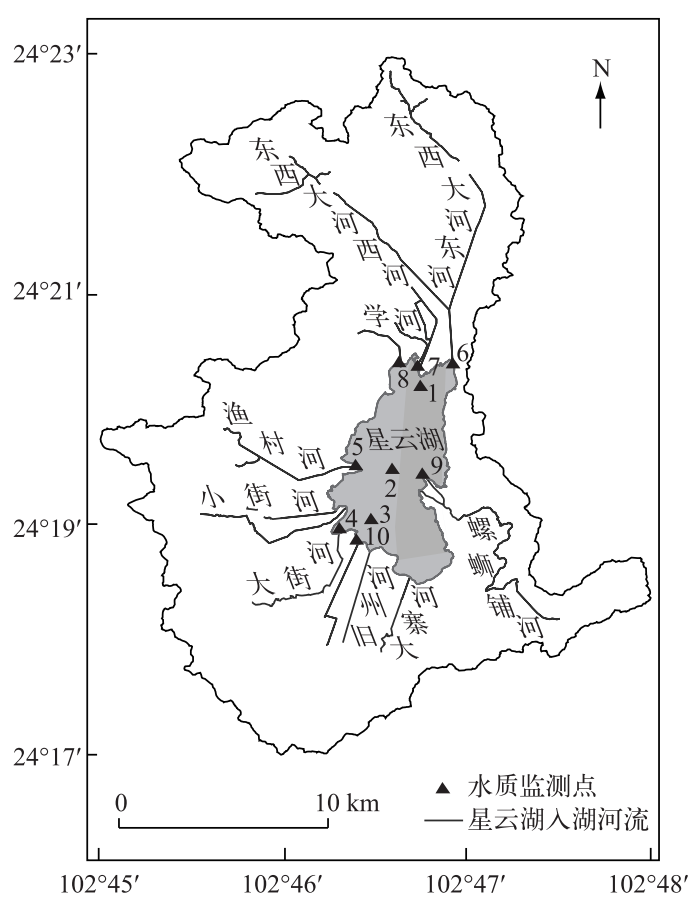

图 1 星云湖流域位置

Fig.1 Location of Lake Xingyun Basin
质的影响.

\section{1 研究区概况和研究方法}

\section{1 研究区概况}

星云湖 $\left(24^{\circ} 17^{\prime} \sim 24^{\circ} 23^{\prime} \mathrm{N}, 102^{\circ} 45^{\prime} \sim 102^{\circ} 48^{\prime} \mathrm{E}\right)$ 位于云南省玉溪市江川区境内, 东临华宁县,西接玉 溪, 南与通海接壤, 北与晋宁、澄江两县为邻, 整个流 域面积为 $389.79 \mathrm{~km}^{2}$ (图 1). 流域内山区半山区约占 $65 \%$,坝区占 $21 \%$, 水域占 $14 \%$, 是一个“七山一水二 坝地” 的高原、中山、湖盆组成的坝区. 属亚热带西南 季风气候, 具有气候温和、四季不分明、干湿季明显 的亚热带半湿润高原季风气候的特点. 多年平均降 雨量 $863.1 \mathrm{~mm}$, 年平均气温 $15.6^{\circ} \mathrm{C}$, 雨季主要集中在 5-10月. 星云湖湖水主要靠地表径流和湖面降水 补给, 周边主要人湖河流有大街河、东西大河、螺蛳 铺河、渔村河等 12 条季节性河流, 总径流面积 310 $\mathrm{km}^{2}$, 占星云湖整个径流区的 $82 \%$, 河道总长 132 $\mathrm{km}$, 多年平均人湖径流量为 6200 万 $\mathrm{m}^{3[12-13]}$.

2015 年末星云湖流域总人口为 19.87 万人, 人 口密度 532 人 $/ \mathrm{km}^{2}$, 其中农村人口 17.23 万人, 占总 人口比重的 $86.7 \%, 2015$ 年星云湖流域经济总产值 为 461949 万元, 其中三产业产值比重为 31.01 : 
40.19：28.8. 星云湖流域近几年经济发展水平加快,其 2015 年人均 GDP 23249 元, 比 2010 年增长了 73.5\%. 然而在社会经济迅速发展的同时,星云湖付出了沉重的生态环境的代价, 1998 年前星云湖为 III 类水质, 2001 年水质类别下降为 $\mathrm{IV}$ 类, 自 2002 年开始下降为 $\mathrm{V}$ 类, 处于中度一重度富营养状态 ${ }^{[3]}$.

\section{2 数据来源}

为了开展星云湖水质变化及其人文因素驱动力研究,收集的数据如表 1 所示.

表 1 数据说明

Tab.1 Data description

\begin{tabular}{|c|c|c|c|}
\hline 数据类型 & 数据内容 & 备注 & 数据来源 \\
\hline 遥感影像 & $\begin{array}{l}2005 \text { 年 } 2 \text { 月 } 1 \text { 日和 } 4 \text { 月 } 13 \text { 日、 } \\
2010 \text { 年 } 2 \text { 月 } 15 \text { 日和 } 11 \text { 月 } 6 \text { 日、 } \\
2015 \text { 年 } 3 \text { 月 } 9 \text { 日和 } 11 \text { 月 } 20 \text { 日 } \\
\text { Landsat } 8 \text { 和 Landsat } 7 \text { ETM 数据 }\end{array}$ & $\begin{array}{l}\text { 得到 } 2005 、 2010 、 2015 \text { 年 } 2 \text { 个季度 } \\
\text { 的农作物种植面积的变化,并得到 } \\
2015 \text { 年土地利用类型图 }\end{array}$ & $\begin{array}{l}\text { 美国地质勘探局 } \\
\text { ( http: // glovis.usgs.gov/) }\end{array}$ \\
\hline 统计年鉴 & $\begin{array}{l}\text { 星云湖流域 } 2005-2015 \text { 年统计数 } \\
\text { 据,包括三产业产值、播种面积、农 } \\
\text { 药化肥使用量、畜禽养殖量等 }\end{array}$ & $\begin{array}{l}\text { 用来说明流域水质变化的人文 } \\
\text { 因子 }\end{array}$ & 江川县统计局 \\
\hline 问卷调查 & $\begin{array}{l}\text { 生产资料 (化肥、农药、农膜) 的使 } \\
\text { 用量,农户的种植意愿, 生活污水 } \\
\text { 排放情况 }\end{array}$ & $\begin{array}{l}\text { 用来说明流域水质变化的人文 } \\
\text { 因子 }\end{array}$ & $\begin{array}{l}\text { 选取江城、大街、前卫、 } \\
\text { 路局、雄关、安化、雄关 } \\
\text { 中 } 34 \text { 个村做问卷 }\end{array}$ \\
\hline 水质数据 & 星云湖水质情况 ( TN、TP、COD) & 表明水质的评判标准 & $\begin{array}{l}\text { 《云南省九大高原湖 } \\
\text { 泊水质分析报告》 }\end{array}$ \\
\hline $\begin{array}{l}\text { 各类水环境规 } \\
\text { 划和评估报告 }\end{array}$ & $\begin{array}{l}\text { 人湖河流的基础数据, 包括河长、 } \\
\text { 河宽、径流量、径流面积、水环境容 } \\
\text { 量等 }\end{array}$ & 用来计算污染足迹 & $\begin{array}{l}\text { 云南省环境监测 中 } \\
\text { 心站 }\end{array}$ \\
\hline
\end{tabular}

\section{3 研究方法}

在研究区水质现状分析的基础上,研究水质在社会经济系统循环过程中人文因素的驱动作用. 首先根 据水质监测数据, 分析星云湖 12 个月的水质月变化特征, 并分析 2005-2015 年 TN、TP、COD 的年变化特 征, 用污染足迹模型分析人湖河流污染物污染足迹及原因,最后运用主成分分析法分析湖泊水质变化的人 文因素驱动力 ${ }^{[14]}$.

污染足迹模型的构建: 星云湖流域水污染属有机物和营养物污染类型 ${ }^{[3]}$, 因此本文选择有机物和氮、磷 营养盐作为主要污染指标. 然后根据污染足迹基本理论 ${ }^{[15]}$, 构建星云湖流域人湖河流的有机物污染足迹 $\left(P F_{\mathrm{COD}}\right)$ 、氮污染足迹 $\left(P F_{\mathrm{N}}\right)$ 和磷污染足迹 $\left(P F_{\mathrm{P}}\right)$ 模型. 污染足迹是指吸纳一定人口产生的污染物实际所需 要具有污染物吸纳功能的土地面积, 本文是指农用地的面积. 污染足迹越大说明该区域人类活动对水质影 响程度越大 ${ }^{[15]}$.

污染足迹模型为:

$$
\begin{gathered}
P F_{\mathrm{COD}}=P_{\mathrm{COD}} / N Y_{\mathrm{COD}} \\
P F_{\mathrm{N}}=P_{\mathrm{N}} / N Y_{\mathrm{N}} \\
P F_{\mathrm{P}}=P_{\mathrm{P}} / N Y_{\mathrm{P}}
\end{gathered}
$$

式中, $P F_{\mathrm{COD}} 、 P F_{\mathrm{N}}$ 和 $P F_{\mathrm{P}}$ 分别为人湖河流的有机物、氮和磷污染足迹 $\left(\mathrm{km}^{2}\right) ; P_{\mathrm{COD}} 、 P_{\mathrm{N}}$ 和 $P_{\mathrm{P}}$ 分别为人湖河流排 人湖泊的有机物、氮和磷含量 $(\mathrm{kg}) ; N Y_{\mathrm{COD}} 、 N Y_{\mathrm{N}}$ 和 $N Y_{\mathrm{P}}$ 分别为人湖后水体对有机物、氮和磷的平均吸纳能力 $\left(\mathrm{kg} / \mathrm{km}^{2}\right)$. 根据《星云湖流域水污染综合防治“十二五”规划》得到星云湖流域人湖河流的水环境容量和人 湖河流进人水体的有机物、总氮和总磷含量. 水体的吸纳能力是由湖泊的水环境容量与湖泊面积比值表示. 在完成有机物、氮和磷污染足迹的计算之后, 本文考虑到产生环境压力的人类活动具有综合性特点, 因此将 3 种污染足迹的加和即总污染足迹作为衡量研究区人文因素驱动力作用的标准.

通过主成分分析法 ${ }^{[16]}$ 得出各种人文因子的贡献率大小并进行排序, 提取主要的人文因子, 解释这些人 
文因子对水质的影响途径 ${ }^{[17]}$.

\section{2 湖泊水质状况及变化趋势分析}

\section{1 湖泊水质数据采集}

星云湖内常规采样点有 3 个, 分别是湖心、李家湾、螺丝铺, 而人湖河流则有 7 个采样点. 这 10 个水质监 测点测定项目包括 $\mathrm{pH}$ 值、溶解氧 $(\mathrm{DO})$ 、五日生化需氧量 $\left(\mathrm{BOD}_{5}\right)$ 、铵态氮 $\left(\mathrm{NH}_{4}^{+}-\mathrm{N}\right)$ 、总磷 $(\mathrm{TP}) 、$ 总氮 $(\mathrm{TN})$ 、 化学需氧量 (COD)、叶绿素等, 监测频率为每月 1 次 (图 1). 本文主要选取测定数据比较全的指标 TP、TN、 COD 进行分析.

\section{2 湖泊水质月变化特征}

选取星云湖 2009-2015 年 TN、TP、COD 浓度的月平均值, 表示星云湖 1-12 月的水质状况; 水质监测 指标中 COD 浓度夏、秋季节的浓度普遍高于春、冬季节, 其中 6 月浓度最高达 $41.07 \mathrm{mg} / \mathrm{L}, 3$ 月浓度最低至 $33.74 \mathrm{mg} / \mathrm{L} ; \mathrm{TN}$ 浓度一年中呈波动变化, 最高浓度出现在 9 月, 最低浓度出现在 3 月; TP 浓度夏季最高, 冬 季最低, 从 3-8 月浓度逐月增加, 8 月至次年 1 月浓度逐月减少. 综合水质得分是运用主成分分析法得出 的 TN、TP、COD 3 个因子综合得分, 数值越大表示水质越差. 结果表明, 3 月水质最好, 9 月水质最差, $3-9$ 月 水质总体变差, 9 月到次年 1 月水质逐月变好 (图 2 ).

\section{3 湖泊水质年变化特征}

在 2005- 2015 年间, TN 的浓度处于先波动后稳定的状态, 2013 年前 $T N$ 浓度一直在 V 类和劣 V 类之间 波动, 达不到 IV 类水的标准,之后稳定在劣 V 类水标准; TP 的浓度 2009 年前稳定在 V 类水标准, 2009 年后 呈先升再降的变化趋势, 均为劣 V 类标准, 其中 2005-2012 年波动上升, 在 2012-2015 年下降; COD 浓度 在这 10 年是波动上升的, 2013 年之前, 大部分年际浓度达到 V 类标准, 只有 2008 年的 COD 浓度为 IV 类标 准,2013-2014 年处于劣 V 类状态,2015 年回到 V 类标准,综合水质得分是运用主成分分析法得出的 $\mathrm{TN}$ 、 TP、COD 3 个因子综合得分, 结果表明,2008 年水质状况最好,2014 年的水质状况最差, 从 2008-2014 年水 质持续变差, 到 2015 年好转( 图 3).

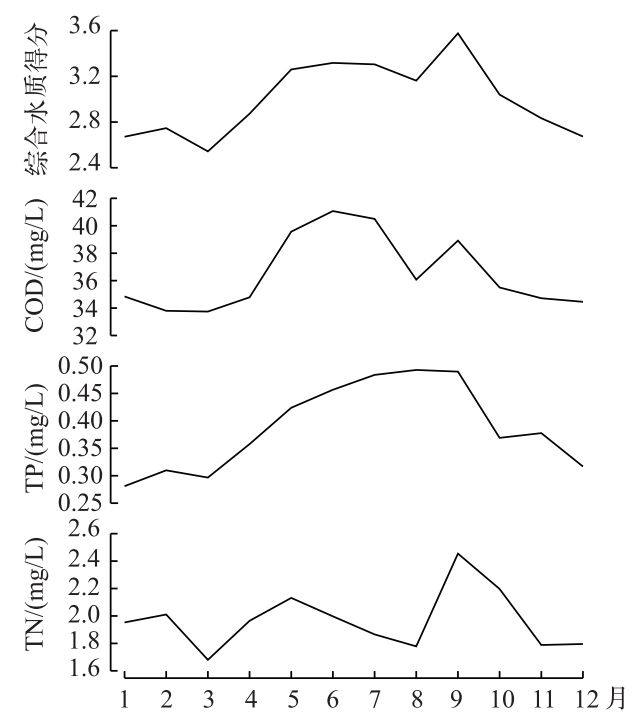

图 2 星云湖 $1-12$ 月 $\mathrm{TN} 、 \mathrm{TP} 、$

$\mathrm{COD}$ 浓度及综合水质变化

Fig.2 Monthly variation of TN, TP and COD concentrations and comprehensive water quality of Lake Xingyun from January to December

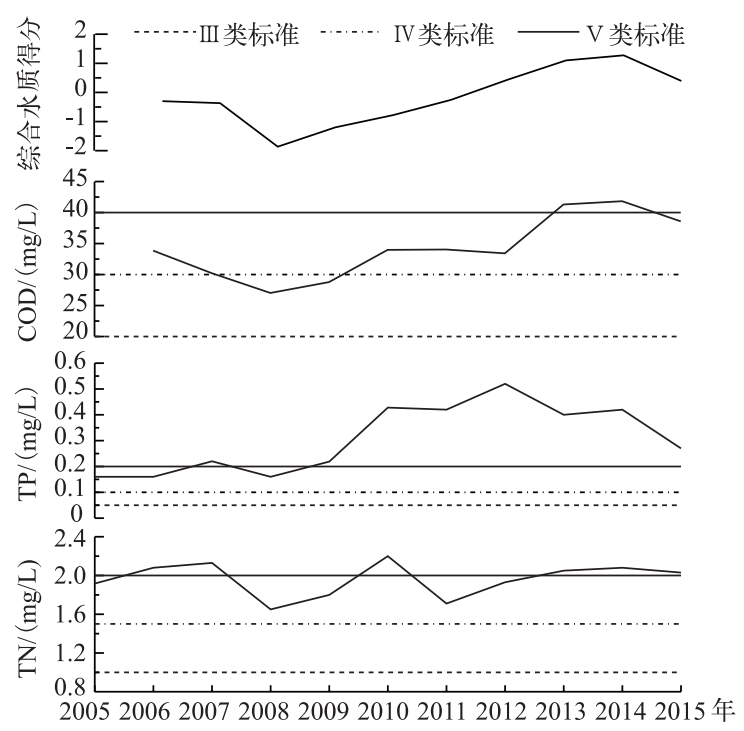

图 3 星云湖 TN、TP、COD 年际浓度及 综合水质变化

Fig.3 Interannual variation of TN, TP and

COD concentrations and comprehensive water quality of Lake Xingyun 


\section{4 入湖河流污染物污染足迹及原因}

2.4.1 入湖河流污染物污染足迹利用污染足迹模型计算得到星云湖流域的有机物、氮和磷污染足迹(表 2), 2015 年星云湖流域有机物、氮和磷的污染足迹分别为 583.26 、705.88 和 $494.11 \mathrm{~km}^{2}$. 人湖河流的污染足 迹从大到小排序为: 大街河 $>$ 东西大河东河 $>$ 渔村河 $>$ 东西大河西河 $>$ 螺蛳铺河 $>$ 大寨河 $>$ 旧洲河 $>$ 周官河 $>$ 小 街河>学河>周德营河 $>$ 大庄河 $>$ 大龙潭河, 大街河、东西大河、渔村河的污染足迹最大, 三者之和占星云湖流 域总污染足迹的 $66.21 \%$. 其中仅大街河和东西大河对 COD 污染足迹的贡献率达 $65.61 \%$, 大街河、东西大 河、渔村河对 TN 污染足迹的贡献率达到 70.69\%,大街河、渔村河、螺蛳铺河、大寨河对 TP 污染足迹的贡献 率达到 66.05\%. 可见,星云湖流域内大街河、渔村河、东西大河对当地水域空间的生态占用是最大的.

表 22015 年星云湖人湖河流各污染指标的污染足迹

Tab.2 Pollution footprint of pollution indicators in inflow rivers of Lake Xingyun in 2015

\begin{tabular}{ccccc}
\hline 河流名称 & 总污染足迹 $/ \mathrm{km}^{2}$ & $\mathrm{COD}$ 污染足迹 $/ \mathrm{km}^{2}$ & $\mathrm{TN}$ 污染足迹 $/ \mathrm{km}^{2}$ & $\mathrm{TP}$ 污染足迹 $/ \mathrm{km}^{2}$ \\
\hline 大街河 & 446.28 & 181.34 & 162.33 & 102.61 \\
大庄河 & 19.03 & 5.87 & 8.65 & 4.51 \\
旧洲河 & 70.95 & 18.40 & 23.08 & 29.47 \\
大寨河 & 144.21 & 38.49 & 47.47 & 58.26 \\
螺蛳铺河 & 171.41 & 28.51 & 52.47 & 90.43 \\
东西大河东河 & 321.89 & 135.14 & 145.63 & 41.12 \\
东西大河西河 & 202.63 & 66.22 & 107.27 & 29.13 \\
学河 & 37.44 & 9.06 & 14.68 & 13.70 \\
周德营河 & 26.83 & 6.13 & 13.01 & 7.69 \\
大龙潭河 & 18.18 & 5.56 & 5.81 & 6.81 \\
渔村河 & 209.84 & 51.02 & 83.76 & 75.06 \\
周官河 & 66.71 & 20.39 & 23.98 & 22.34 \\
小街河 & 47.84 & 17.14 & 17.72 & 12.98 \\
合计 & 1783.25 & 583.26 & 705.88 & 494.11 \\
\hline
\end{tabular}

2.4 .2 基于土地利用类型的污染足迹分析 借鉴燕姝雯 $^{[18]}$ 、杨莎莎等 $^{[19]}$ 和王鹏等 $^{[20]}$ 对人湖河流缓冲区半径 的选取方法, 最终对半径为 $250 \mathrm{~m}$ 的缓冲区进行分析. 污染足迹最大的 3 条河流周围, 土地利用类型为水 田、旱地和村庄 (图 4). 大街河周边 $250 \mathrm{~m}$ 缓冲区内土地利用类型主要为水田和城镇建设用地, 面积占缓冲 区内总面积的 $74.37 \%$, 渔村河主要为水田, 面积占 51.47\%, 东西大河主要为水田和旱地, 面积占 56.84\% (图 4 和图 5). 而 TN、TP 浓度排序从大到小排序皆为: 大街河>螺蛳铺河 >大庄河 > 小街河>东西大河西河, TN、 $\mathrm{TP}$ 的主要来源是农药化肥, 水田和旱地种植使用的化肥农药大量流失, 使得周边河流的 TN TP 浓度增大, 所以, 水田和旱地分布广及其大量施用化肥农药是导致东西大河和渔村河污染足迹大的主要原因; COD 浓 度排序从大到小排序为: 大街河 $>$ 大寨河 $>$ 旧州河 $>$ 周德营河 $>$ 东西大河西河, 村庄的养殖户较多, 养殖业的 畜禽粪便通过地表径流排人河流, 加上村庄中居民生活污水的排放, 使得 COD 浓度增大, 所以大街河周边的 村庄是导致大街河的污染足迹最大的主要原因 ( 图 5 ).

\section{3 湖泊水质变化的人文因素驱动力分析}

\section{1 人文因素驱动力的主成分分析}

近 10 年来, 星云湖流域内人均 GDP 迅速上升, 城镇用地比重增加, 耕地面积比重减少, 产业结构也处于 初级阶段, 总体污染排放量呈增长趋势. 为了揭示影响星云湖流域水质变化的因素, 首先初步选择影响水质 的相关人文因素, 然后根据多元统计分析方法找出主成分进行因子分析, 结合 2005-2015 年的土地转移矩 阵和人湖河流的污染足迹, 得出影响星云湖水质程度最大的人文因子.

选择 2005-2015 年星云湖水质的 TN、TP、COD 3 个指标 Y1、Y2、Y3 为因变量, 总人口 X1、人均 GDP X2、第一产业产值 X3、第二产业产值 X4、第三产业产值 X5、播种面积 X6（包括粮食播种面积、油料播种面 


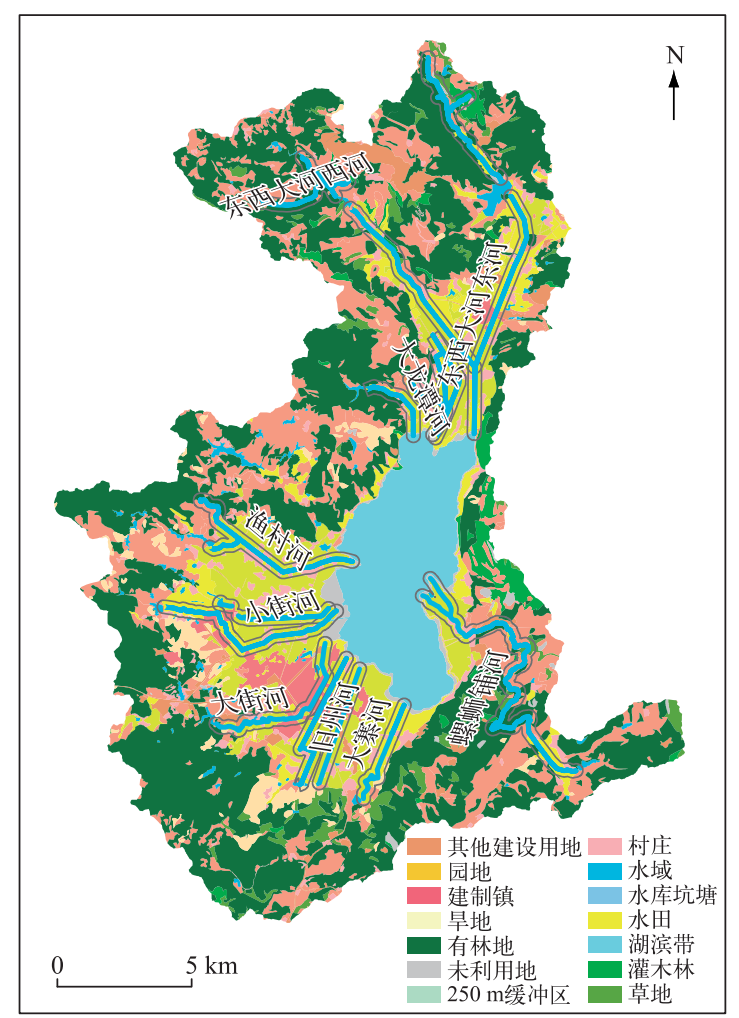

图 42015 年星云湖流域的土地利用类型

Fig.4 Land use types in Lake Xingyun Basin in 2015

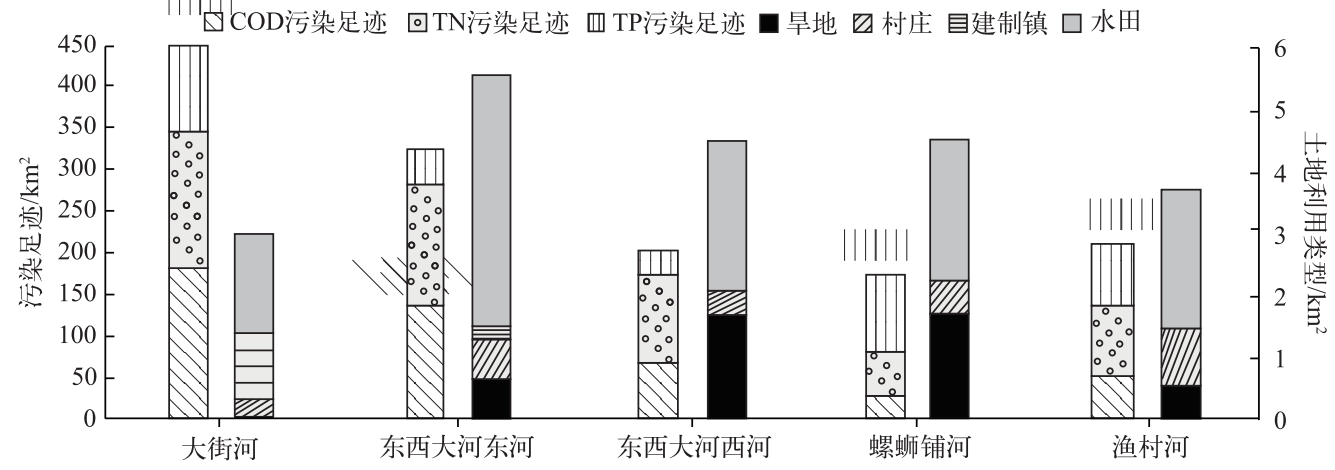

图 52015 年星云湖主要人湖河流污染足迹及 $250 \mathrm{~m}$ 缓冲区内主要土地利用类型的面积

Fig.5 Pollution footprint of main inflow rivers of Lake Xingyun and areas of main land use types in $250 \mathrm{~m}$ buffer zone

积、蔬菜播种面积）、农村人口 X7、农药使用量 X8、化肥使用量 X9、农膜使用量 X10、大牲畜存栏量 X11 等指 标为自变量作为原始数据, 应用统计分析软件 SPSS 19.0, 对样本先进行标准化再进行分析计算, 指标综合得 出相关系数矩阵、特征值、主成分贡献率与累积贡献率表. 相关系数矩阵的结果表明影响星云湖流域水质的 11 个人文因子之间有较高的相关性,可以进行主成分分析.

主成分分析结果表明, 有两个特征值大于 1 , 它们已包含 $80 \%$ 以上的贡献率 (表 3 ), 对大多数指标已给出 充分的概括,所以可以确定提出 2 个主成分. 第 1 、第 2 主成分的累积贡献率已达 $96.965 \%$,完全符合分析要求.

第 1 主成分 (总人口、播种面积 (包括粮食播种面积、油料播种面积、蔬菜播种面积)、农村人口、农药使 
用量、化肥使用量、农膜使用量、大牲畜存栏量) 包含 $84.389 \%$ 的贡献率, 是主控因子,表示与农村生活和农 业面源污染有关的因素; 第 2 主成分 (人均 GDP、第一产业产值、第二产业产值、第三产业产值) 的贡献率为 $12.576 \%$, 表示了与社会经济发展有关的因素, 星云湖流域社会经济发展带来用水量及排污的增长, 导致水 质变坏. 因此,星云湖流域水质变化的人文因素驱动力可以归纳为农村生活和农业面源污染类、社会经济发 展类(图 6),其中农村生活和农业面源污染是水质变化的主要驱动力.

表 3 特征值及主成分贡献率

Tab.3 Eigenvalue and principal

component contribution rate

\begin{tabular}{cccc}
\hline 主成分 & 特征值 & 贡献率\% & 累计贡献率\% \\
\hline 1 & 11.814 & 84.389 & 84.389 \\
2 & 1.761 & 12.576 & 96.965 \\
3 & 0.337 & 2.408 & 99.372 \\
4 & 0.047 & 0.336 & 99.708 \\
5 & 0.032 & 0.228 & 99.937 \\
6 & 0.006 & 0.042 & 99.978 \\
7 & 0.003 & 0.019 & 99.997 \\
8 & 0.001 & 0.003 & 100 \\
9 & $2.53 \times 10^{-16}$ & $1.81 \times 10^{-15}$ & 100 \\
10 & $2.28 \times 10^{-16}$ & $1.63 \times 10^{-15}$ & 100 \\
11 & $2.60 \times 10^{-17}$ & $1.86 \times 10^{-16}$ & 100 \\
\hline
\end{tabular}

\section{2 人文驱动因子分析}

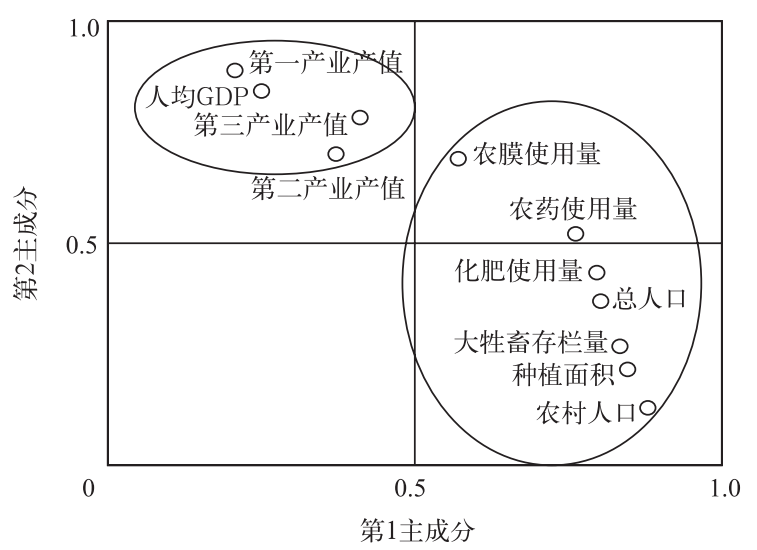

图 6 各因子对主成分贡献率分布

Fig.6 Contribution rate distribution of each factor to principal component

以下从入湖河流流域来分析各污染源的污染因子,流域划分区域见图 7.

3.2 .1 农村生活和农业面源污染因子分析 总人口、播 种面积、农村人口、农药使用量、化肥使用量、农膜使用 量、大牲畜存栏量, 这 7 个因子反映了人类生产活动中 农村生活和农业面源污染对水质的影响. 具体体现在 流域内总人口和农村人口增多, 即该流域的人口密度 增大, 人口排序前 4 位的流域分别为: 大街河流域>渔 村河流域>东西大河东河流域>东西大河西河流域 (表 4), 这 4 个流域的人口占总人口的 $57.3 \%$, 意味着这 4 条人湖河流承受的人口压力大, 大街河流域人口最多, 居民生活污水产污量最大, 几乎没有任何生活污水收 集和处理措施,生活中各种洗涤剂的使用使 TP 浓度升 高, 水质变差.

播种面积对水质的影响解析. 农作物的种植土地 利用类型为水田和旱地,水田、旱地排序前 4 位的流域 为: 渔村河流域 $>$ 螺蛳铺河流域 $>$ 大寨河流域 $>$ 东西大 河东河流域. 渔村河流域的水田、旱地的面积之和达到 $57.11 \mathrm{~km}^{2}$, 水田、旱地的面积越大,农作物的播种面积 越大, 其中全流域的普遍趋势是粮食播种面积呈波动 状态, 基本保持稳定, 而油料和蔬菜呈递增趋势. 结合 问卷调查,农户的种植意愿越来越倾向于经济作物 (油 料、蔬菜), 而经济作物所需农药化肥量大于粮食作物, 其中经济作物的农药使用量为 $40.95 \mathrm{~kg} / \mathrm{hm}^{2}$, 化肥施

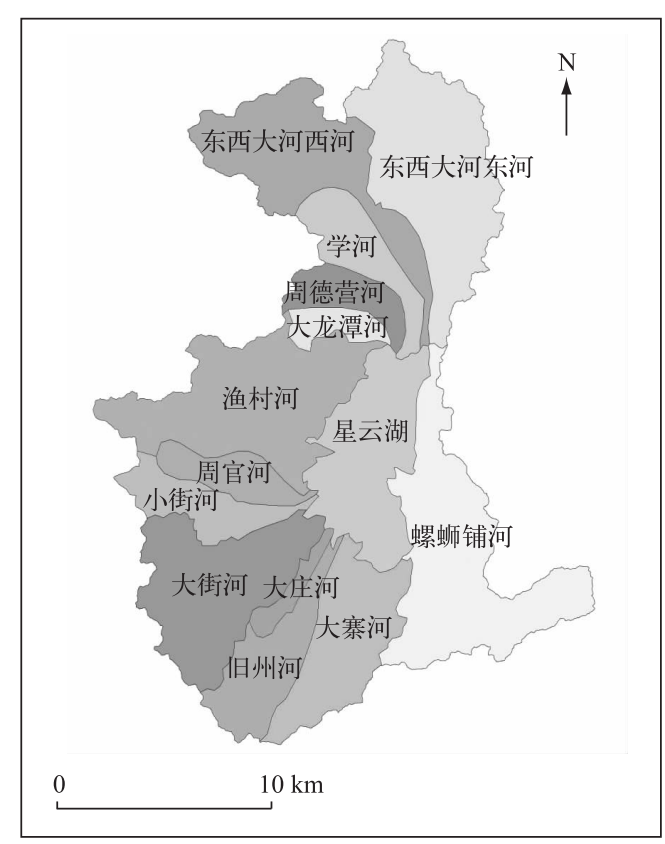

图 72015 年星云湖人湖河流流域划分

Fig.7 Division of inflow river basins of Lake Xingyun Basin in 2015 
用量为 $5250 \mathrm{~kg} / \mathrm{hm}^{2}$, 粮食作物的农药使用量为 $10.2 \mathrm{~kg} / \mathrm{hm}^{2}$, 化肥施用量为 $1650 \mathrm{~kg} / \mathrm{hm}$; 并且经济作物的肥 料流失量也大于粮食作物, 其中露地蔬菜的 $\mathrm{TN}$ 流失系数为 $22.5 \mathrm{~kg} / \mathrm{hm}^{2}$, $\mathrm{TP}$ 流失系数为 $1.38 \mathrm{~kg} / \mathrm{hm}^{2}$, 而水 稻的 TN 流失系数为 $19.335 \mathrm{~kg} / \mathrm{hm}^{2}$, TP 流失系数为 $0.45 \mathrm{~kg} / \mathrm{hm}^{2}$. 经济作物播种面积越大, 使用的农药、化肥 量越多, 而农药中的氮磷元素和化肥中氮肥、磷肥中流失的 TN、TP 通过降雨地表径流和地下淋溶的方式进 人湖泊, 对湖泊水质带来影响. 综上可知, 渔村河流域种植业污染最为严重, 渔村河流域、螺蛳铺河流域、大 寨河流域 3 个流域的水田、早地之和占总流域的 $72.33 \%$, 并且与星云湖接壤面最大, 种植业流失的 TN、TP 通过面源流失的途径直接进人星云湖内, 对水质造成严重影响.

农药使用量、化肥使用量和农膜使用量是直接影响因子, 使用在种植业上, 同上述一样体现在水田、旱地 上. 因农药化肥中直接含有 TN 和 TP, 2015 年渔村河流域内化肥施用量达 $5590.54 \mathrm{t}$, 整个流域化肥施用量高达 $30196.3 \mathrm{t}$. 化肥与人、畜肥施用比例由 $1970 \mathrm{~s}$ 的 $1: 9$ 上升至目前的 $8: 2^{[21]}$, 农药的使用量也从 2005 年的 $171.5 \mathrm{t}$ 上升到 2015 年的 $399 \mathrm{t}$, 翻了一翻. 使用的农膜会残留在土壤中, 破坏土壤的透气性, 阻碍土壤水肥的流转, 影 响作物对水分和养分的吸收, 降低土壤蓄水能力 ${ }^{[22]}$. 这一系列的污染会导致作物产量和产品质量下降, 而农户 为了保证作物产量不下降而施用大量的农药化肥, 如此导致 TN、TP 流失人湖的浓度超标,致使水质变差.

大牲畜存栏量可以反映畜禽养殖的排污量, 其排序前 4 位的流域为: 渔村河流域>螺蛳铺河流域>东西 大河东河流域>东西大河西河流域. 这 4 个流域的大牲畜存栏量占整个流域的 $75.6 \%$, 其中仅渔村河流域大 牲畜存栏量高达 2012 头, 流域的畜禽粪便是湖泊水质营养化主要来源之一 ${ }^{[23]}$, 这些畜禽的粪便大多数未经 过处理或处理未达标便排入湖泊,会导致湖泊水质指标 COD 升高.

综上而述, 从生活污水排放程度、种植业污染程度和畜禽养殖排污程度方面综合考虑, 污染程度大的小 流域有渔村河、大街河、东西大河和螺蛳铺河,和之前污染足迹的计算结果吻合.

3.2.2 社会经济发展因子分析 人均 GDP、第一产业产值、第二产业产值、第三产业产值, 这 4 个因子反映了 人类社会经济发展对水质的影响.

具体体现在人均 GDP、三产业产值越大, 表明流域内经济发展程度越高, 其中人均 GDP 排序前 4 位的 流域为:螺蛳铺河流域>大龙潭河流域>大街河流域>渔村河流域;第一产业产值排序前 4 位的流域为: 螺蛳 铺河流域>渔村河流域>东西大河东河流域>东西大河西河流域; 第二产业产值排序前 4 位的流域为: 大街河 流域>大寨河流域>旧州河流域>渔村河流域; 第三产业产值排序前 4 位的流域为: 大街河流域>东西大河东 河流域>渔村河流域>大寨河流域 (表 4).

表 42015 年星云湖各人湖河流流域的驱动因子概况

Tab.4 Driving factors of each inflow river basin of Lake Xingyun Basin in 2015

\begin{tabular}{|c|c|c|c|c|c|c|c|c|}
\hline 人湖河流流域 & 人口/人 & 大牲畜/头 & $\begin{array}{c}\text { 早地面积/ } \\
\mathrm{km}^{2}\end{array}$ & $\begin{array}{c}\text { 水田面积/ } \\
\mathrm{km}^{2}\end{array}$ & $\begin{array}{c}\text { 人均 GDP/ } \\
\text { 元 }\end{array}$ & $\begin{array}{c}\text { 第一产业产 } \\
\text { 值/万元 }\end{array}$ & $\begin{array}{c}\text { 第二产业产 } \\
\text { 值/万元 }\end{array}$ & $\begin{array}{c}\text { 第三产业产 } \\
\text { 值/万元 }\end{array}$ \\
\hline 大街河流域 & 30832 & 323 & 5.05 & 1.06 & 16694.91 & 9961.30 & 47996.23 & 22290.23 \\
\hline 大龙潭河流域 & 437 & 325 & 0.14 & - & 36745.99 & 11667.00 & 1183.00 & 3208.00 \\
\hline 大寨河流域 & 21783 & 235 & 5.17 & 17.25 & 8121.95 & 7227.42 & 34823.68 & 16172.69 \\
\hline 大庄河流域 & 3356 & 35 & 0.94 & 0.11 & 846.98 & 1084.33 & 5224.62 & 2426.40 \\
\hline 东西大河东河流域 & 28729 & 1319 & 14.27 & 4.25 & 7741.90 & 16958.69 & 12428.73 & 20875.33 \\
\hline 东西大河西河流域 & 22370 & 1000 & 7.01 & 0.40 & 6069.90 & 12858.42 & 9423.71 & 15828.09 \\
\hline 旧州河流域 & 15129 & 159 & 1.39 & & 3692.29 & 4887.95 & 23551.47 & 10937.69 \\
\hline 螺蛳铺河流域 & 13502 & 1574 & 16.36 & 6.41 & 47528.98 & 28700.00 & 17260.00 & 12504.00 \\
\hline 小街河流域 & 9181 & 93 & 0.77 & 0.04 & 10705.46 & 5237.32 & 6688.55 & 4683.59 \\
\hline 学河流域 & 8682 & 399 & 2.86 & 0.09 & 5190.76 & 5124.79 & 3755.87 & 6308.37 \\
\hline 渔村河流域 & 31982 & 2012 & 17.11 & 39.99 & 11996.08 & 18244.33 & 23299.75 & 16315.40 \\
\hline 周德营河流域 & 5729 & 263 & 0.55 & - & 4963.25 & 3382.10 & 2478.68 & 4163.20 \\
\hline 周官河流域 & 7069 & 72 & 0.21 & - & 5688.92 & 4032.35 & 5149.70 & 3606.02 \\
\hline 总计 & 198781 & 7809 & 71.83 & 69.60 & 165987.00 & 88999.00 & 174821.00 & 123607.00 \\
\hline
\end{tabular}


综合得知, 在整个大流域内螺蛳铺河流域和渔村河流域以第一产业为主, 流域主要种植烤烟、蔬菜, 销 往省内, 第一产业产值越大, 即种植业和养殖业的产值越大, 种植业和养殖业的发展需要湖泊水, 同时还会 将污水排人湖泊, 导致 TN、TP、COD 浓度超标, 湖泊水质变差. 大街河流域以第二、三产业为主, 流域内具有 丰富的硅石、方铅石、橄榄石、赤铜矿、芒硝、膨润土,第二产业在持续发展,但工厂一年用水量约 300 万 $\mathrm{t}$, 产 生的污染物一部分收集至城市污水处理厂处理, 达标排人湖泊,一部分直接排放, 工厂污水中含有大量的氮 磷元素和有机物, TN 、TP、COD 浓度超标, 致使湖泊水质恶化. 服务业的发展一方面导致生活污水排放量增 多, 由于流域内居民生活污水排放方式是直排, 产生量等于排放量, 污水排放量约为 120 万 $\mathrm{t} / \mathrm{a}$; 另一方面导 致住宿餐饮产污量的增多, 酒店污染负荷中, 污水排放量约为 18 万 $\mathrm{t} / \mathrm{a}$, 垃圾排放量为 24.93 万 $\mathrm{t} / \mathrm{a}$, 这些污 水和垃圾进人湖泊,主要会引起 TN、TP 污染物浓度超标, 对湖泊水质造成影响.

\section{4 讨论}

\section{1 对研究方法的讨论}

从研究方法上看, 早期学者有关流域水质污染特征的研究大多数以定性分析为主, 即论述产业结构的 变化、农药化肥的使用、畜禽养殖粪便和生活废水的排放等因素对流域水质产生影响 ${ }^{[24-28]}$. 由于受到认识程 度和技术手段的限制, 定性分析难以明确表示流域水污染的程度. 随着城市化进程的加快, 人类活动对水质 的影响程度越来越大, 污染足迹模型可以较好地衡量流域人类活动对水质的影响, 因此用污染足迹模型计 算星云湖流域人湖河流的污染足迹,可以反映人类活动对水质的影响.

利用主成分分析方法研究水环境变化的驱动力因素时, 多数学者 ${ }^{[29-31]}$ 都趋向于研究自然因素驱动力, 只有少数学者 ${ }^{[22-33]}$ 研究人文因素驱动力. 特别是星云湖流域水质研究中, 只有极少学者的研究涉及人文因 素驱动力, 本研究关注星云湖流域人文因素驱动力, 并深人分析人文因素中的影响因子, 揭示农村生活污水 和农业面源污染是星云湖水质变化的主要驱动力.

\section{2 对研究结果的讨论}

焦雯珺等 ${ }^{[33}$ 利用污染足迹模型对整个太湖流域的污染足迹进行计算分析, 污染足迹最大的是 TP, 而本 研究的星云湖流域污染足迹最大的是 $\mathrm{TN}$, 这源于星云湖流域农业种植氮肥的大量使用; 太湖流域没有计算 湖泊人湖河流的污染足迹, 也没有进一步深人分析污染足迹大小的影响因素, 而本研究利用污染足迹模型 计算星云湖人湖河流的污染足迹, 并对人湖河流周边 $250 \mathrm{~m}$ 的缓冲区的土地类型进行分析, 认为人湖河流 周围水田、旱地中农药、化肥的流失对河流水质影响最大, 其次是村庄的畜禽粪便的排放.

在人文因素方面, 本研究通过主成分分析得出农村生活和农业面源污染是星云湖水质恶化的主要驱动 力, 这与刘慧丽等 ${ }^{[34]}$ 对鄱阳湖流域生态环境变化及驱动力分析, 和李兆富等 ${ }^{[35]}$ 对太湖地区水体富营养化的 主要因子分析结果一致; 李荫尔等 ${ }^{[36]}$ 得出星云湖人湖河流的污染负荷的 $80 \%$ 来自面源污染, 其中主要来源 是农药化肥流失人湖、径流区人口增加和畜禽粪便流失汇人河流直接人湖 3 个方面, 与本研究对入湖河流 的分析结果相似, 本研究更加深人地将 13 条人湖河流与土地利用类型相结合, 得出人湖河流的主要驱动力. 当前, 对湖泊水污染的问题要注重对面源污染物质的形成过程及其量化进行研究 ${ }^{[37-39]}$. 然而本研究没有进 一步定量分析确定对农业面源污染贡献率最大的因子, 只是定性的分析了农药化肥的使用对农业面源污染 的贡献. 因此下一步的工作应注重农村生活和农业面源污染在 2005-2015 年的时空演变特征以及水质的 变化,并提出相应的防控措施.

\section{5 结论}

基于星云湖流域水质数据、遥感数据和统计数据, 定量分析了 2005-2015 年水质时间变化趋势和 2015 年人湖河流污染物污染足迹及与土地利用的关系, 鉴别了星云湖水质变化的人文驱动因素.

1) 水质月变化趋势表明, 1 月份水质最好, 11 月份水质最差,全年水质变化不大. 从 2005-2015 年的年 变化特征来看, 2008 年水质状况最好, 2014 年水质状况最差, 从 2008-2014 年水质持续变差,到 2015 年出 现好转趋势.

2) 遥感影像解译结果和计算的污染足迹结果表明, 2015 年有机物、氮和磷的污染足迹分别为 583.26 、 
705.88 和 $494.11 \mathrm{~km}^{2}$. 污染足迹排在前 4 位的人湖河流为: 大街河>东西大河东河>渔村河>东西大河西河, 前 4 位之和占星云湖流域总污染足迹的 $66.21 \%$. 污染程度较大的大街河、东西大河和渔村河周边土地利用 类型为水田、旱地和村庄.

3 ) 通过主成分分析,星云湖水质影响因素第 1 主成分 (总人口、播种面积、农村人口、化肥使用量、农膜 使用量、大牲畜存栏量) 表示与农村生活和农业面源污染有关的因素; 第 2 主成分 (人均 GDP、第一产业产 值、第二产业产值、第三产业产值) 表示与社会经济发展有关的因素. 因此,星云湖流域水质变化的人文因素 驱动力可以归纳为农村生活和农业面源污染类和社会经济发展类, 其中第 1 主成分的贡献率为 $84.389 \%$, 农 村生活和农业面源污染是水质变化的主要驱动力, 流域内人口密度增大、畜禽存栏量逐年升高和种植业粮 食作物转经济作物,导致了水质恶化.

\section{6 参考文献}

[ 1 ] Yu Y, Zhang M, Qian SQ et al. Current status and development of water quality of lakes in Yunnan-Guizhou Plateau. $J$ Lake Sci, 2010, 22(6) : 820-828. DOI: 10.18307/2010. 0603. [于洋, 张民, 钱善勤等. 云贵高原湖泊水质现状及 演变. 湖泊科学, 2010, 22(6): 820-828.]

[ 2 ] Li K, Wang L, Li ZH et al. Spatial variability characteristics of water quality and its driving forces in Honghu Lake during high water- level Period. Environmental Science, 2015, 36(4) : 1285-1292. [李昆, 王玲, 李兆华等. 丰水期洪湖水质 空间变异特征及驱动力分析. 环境科学, 2015, 36(4) : 1285-1292.]

[ 3 ] Feng M. Assessment of water quality and analysis on cause of formation of eutrophication in Xingyunhu Lake. Yunnan Environment Science, 2005, 24(z2) : 96-99. [冯梅. 星云湖水质评价及富营养化成因分析. 云南环境科学, 2005, 24 (z2) : 96-99.]

[ 4 ] Li SH, Yu MJ, Li GZ et al. Limnological survey of the lakes of Yunnan Plateau. Oceanologia et Limnologia Sinica, 1963, 5(2) : 87-114. [黎尚豪, 俞敏娟, 李光正等. 云南高原湖泊调查. 海洋与湖沼, 1963, 5(2) : 87-114.]

[ 5 ] Zhang W, Ming Q, Shi $Z$ et al. Lake sediment records on climate change and human activities in the Xingyun Lake Catchment, SW China. PloS One, 2014, 9(7): e102167.

[ 6 ] Zhang H, Li S, Feng Q et al. Environmental change and human activities during the 20th century reconstructed from the sediment of Xingyun Lake, Yunnan Province, China. Quaternary International, 2010, 212(1):14-20.

[ 7 ] Zhang J, Zhang Z. A study of remote sensing investigation for water quality pollution of the Fuxian and Xingyun Lakes in Yunnan Province using MODIS data. Hydrogeology \& Engineering Geology, 2008, 35(5) : 92-96. [ 张洁, 张志. 基于 MODIS 数据的云南抚仙湖星云湖水质污染遥感调查方法研究. 水文地质工程地质, 2008, 35(5): 92-96.]

[ 8 ] Fukushima T, Ozaki N, Kaminishi H et al. Forecasting the changes in lake water quality in response to climate changes, using past relationships between meteorological conditions and water quality. Hydrological Processes, 2000, 14 (3): 593-604.

[ 9 ] Qin J, Wu XH, Wu B et al. Phytoplankton and water environment in Xinyun Lake: Characteristics study and correlation analysis. Environmental Science \& Technology, 2012, 35(6): 46-50. [秦洁, 吴献花, 吴斌等. 星云湖浮游植物和水环 境特征研究及相关性分析. 环境科学与技术, 2012, 35(6): 46-50.]

[10] Zhang YY, Xie ML, Liu SS et al. The analysis of water quality change trend for Lake Fuxian \& Lake Xingyun. Geographical Science Research, 2015, 4(3): 81-94. [张云鹰, 谢曼平, 刘姗姗等. 抚仙湖和星云湖水质变化趋势分析. 地理 科学研究, 2015, 4(3): 81-94.]

[11] Xu JY, Zhao XF, Lü CY et al. Study on water environment pollution characteristics and comprehensive regulation of Xingyun Lake Watershed. Shenzhen: China Environmental Science Society Annual Meeting, 2015. [许杰玉, 赵晓飞, 吕 春英等. 星云湖流域水环境污染特征分析与综合整治研究. 深圳: 中国环境科学学会学术年会, 2015.]

[12] Wang JH. The research of xingyun lake vellay raising livestock pollution characters and quantitative estimation [Dissertation]. Kunming: Kunming University of Science and Technology, 2011. [王晋虎. 星云湖流域畜禽养殖污染特征及其 定量估算研究[学位论文]. 昆明: 昆明理工大学, 2011.]

[13] Yuxi Municipal People's Government. Xingyun Lake basin water environment protection 12th Five-Year plan report (20112015)，2011. [玉溪市人民政府. 星云湖流域水环境保护“十二五”规划报告 (2011-2015)年, 2011.]

[14] Wan JB, He HY, Zeng HY et al. Application of principle component analysis in evaluating water quality of Poyang Lake. 
Journal of Nanchang University: Engineering \& Technology, 2010, 32(2) : 113-117. [万金保, 何华燕, 曾海燕等. 主 成分分析法在鄱阳湖水质评价中的应用. 南昌大学学报: 工科版, 2010, 32(2) :113-117.]

[15] Min QW, Jiao WJ, Cheng SK. Pollution footprint: A type of ecological footprint based on ecosystem services. Resources Science, 2011, 33(2) : 195-200. [闵庆文, 焦雯珺, 成升鬼. 污染足迹: 一种基于生态系统服务的生态足迹. 资源科 学, 2011, 33(2): 195-200.]

[16] Wang YH, Wang GL. Water quality evaluation of Taihu Lake based on principal component analysis and geostatistical analyst. Environmental Science and Technology, 2010, (s2) : 547-550. [王艳红, 王桂玲. 基于主成分和地统计的太湖水 质分析. 环境科学与技术, 2010, (s2) : 547-550.]

[17] Aynur - Mamat, Qiu YB. The water resources change and its driving force analysis in Hotan Oasis during the past 20 years. Journal of Arid Land Resources and Environment, 2013, 27(4): 117-122. [阿依努尔・买买提, 邱玉宝. 近 20 年和田 绿洲水资源变化及其驱动力分析. 干旱区资源与环境, 2013, 27(4) : 117-122.]

[18] Yan SW. Research on inflow and outflow river pollution characteristics in Lake Taihu Basin[Dissertation]. Beijing: China Environmental Science Research Institute, 2011. [燕姝雯. 太湖流域出入湖河流水污染特征研究 [ 学位论文]. 北京: 中国环境科学研究院, 2011.]

[19] Yang SS, Tang CW, Liu LJ et al. Relationships between river water quality and land use type at watershed scale. Chinese Journal of Applied Ecology, 2013, 24(7) : 1953-1961. [杨莎莎, 汤萃文, 刘丽娟等. 流域尺度上河流水质与土地利 用的关系. 应用生态学报, 2013, 24(7): 1953-1961.]

[20] Wang P, Qi SH, Chen B. Influence of land use on river water quality in the Ganjiang basin. Acta Ecologica Sinica, 2015, 35(13) : 4326-4337. [王鹏, 齐述华, 陈波. 赣江流域土地利用方式对河流水质的影响. 生态学报, 2015, 35(13): 4326-4337. ]

[21] Wang L, Liu Y, Qi YK et al. Investigation on livestock and poultry breeding pollution to water body in Fuxian Lake Basin. Hubei Agricultural Sciences, 2012, 51(15) : 3287-3289. [王林, 刘宇, 祁云宽等. 畜禽养殖业对抚仙湖水质污染调 查. 湖北农业科学, 2012, 51(15): 3287-3289.]

[22] Wang ZC, Li XY, Shi HB et al. Effects of residual plastic film on soil hydrodynamic parameters and soil structure. Transactions of the Chinese Society for Agricultural Machinery, 2015, 46(5): 101-106. [王志超, 李仙岳, 史海滨等. 农膜残 留对土壤水动力参数及土壤结构的影响. 农业机械学报, 2015, 46(5): 101-106.]

[23] Fan GR, Zhu DN, Deng L. Causes of eutrophication and progress of integrated management technology in lake. Journal of Water Resources and Water Engineering, 2010, 21(6): 48-52. [范荣桂, 朱东南, 邓岗. 湖泊富营养化成因及其综合 治理技术进展. 水资源与水工程学报, 2010, 21(6) : 48-52.]

[24] Feng MG. Study on environmental status and sustainable development of Xingyun Lake in Yuxi City [Dissertation]. Kunming: Kunming University of Science and Technology, 2005. [冯明刚. 玉溪市星云湖环境现状及可持续发展研究 [学 位论文]. 昆明: 昆明理工大学, 2005.]

[25] Sun JH, Ni SH, Yan ZJ. Study on effect of human activities on water environment evolution in Taihu Lake region. Jounal of Water Resources and Water Engineering, 2006, 17(1): 7-10. [孙金华, 倪深海, 颜志俊. 人类活动对太湖地区水环 境演变的影响研究. 水资源与水工程学报, 2006, 17 (1): 7-10.]

[26] Jin XL, Gao JF, Zhao GJ. Impacts of 20-year socio-economic development on the trend of aquatic environment of the Taihu Basin. Resources and Environment in the Yangtze Basin, 2006, 15(3): 298-302. [靳晓莉, 高俊峰, 赵广举. 太湖流域 近 20 年社会经济发展对水环境影响及发展趋势. 长江流域资源与环境, 2006, 15(3) : 298-302.]

[27] Zhang HY. Study on adjustment of industrial structure based on environmental capacity[Dissertation]. Shanghai: East China Normal University, 2009. [张海燕. 基于环境容量的产业结构优化设计 [学位论文]. 上海: 华东师范大 学, 2009.]

[28] Qiu C, Ye CL. Analysis of livestock and poultry pollution in Jiangchuan County and countermeasures. Shenzhen: China Environmental Science Society Annual Meeting, 2015. [ 邱成, 叶春丽. 江川县畜禽污染分析与防治对策. 深圳: 中国 环境科学学会学术年会, 2015.]

[29] Liu YY, Chen GJ, Shi HB et al. Responses of a diatom community to human activities and climate changes in Xingyun Lake. Acta Ecologica Sinica, 2016, 36(10) : 3063-3073. [刘园园, 陈光杰, 施海涁等. 星云湖硅藻群落响应近现代 人类活动与气候变化的过程. 生态学报, 2016, 36(10): 3063-3073.]

[30] Shen YQ, Wang HJ, Liu XQ. Aquatic flora and assemblage charcteristics of submergrd macrophytes in five lakes of the 
central yunnan province. Resources and Environment in the Yangtze Basin, 2010, 19(z1): 111-(s1):111-119. [沈亚强, 王海军, 刘学勤. 滇中五湖水生植物区系及沉水植物群落特征. 长江流域资源与环境, 2010,19(z1): 111-(s1): 111-119.]

[31] Yang ZB, Li CF, Lü W. Principal Component Analysis (PCA) study on pollution source of in Xingyun Lake. Forum on ecological city establishment and agricultural sustainable development in Yuxi, 2006: 21-24. [杨中宝, 李朝峰, 吕伟. 星云湖污染源的主成分分析 (PCA) 研究. 玉溪市“生态立市与农业可持续发展”论坛, 2006: 21-24.]

[32] Zhang M, Gong ZN, Zhao WJ. Analysis of driving forces of Baiyangdian wetland evolution during 1984-2013. Chinese Journal of Ecology, 2016, 35(2):499-507. [张敏, 宫兆宁, 赵文吉. 近 30 年来白洋淀湿地演变驱动因子分析. 生 态学杂志, 2016, 35(2): 499-507.]

[33] Jiao WJ, Min QW, Cheng SK. An assessment of human-induced drivers of water environment changes in the Taihu Lake Basin based on a pollution footprint model: A case study of Changzhou City, Jiangsu Province. Resources Science, 2011, 33(2) : 223-229. [焦雯珺, 闵庆文, 成升魁等. 基于污染足迹模型的太湖流域水环境演变的人文驱动力评估一 以江苏省常州市为例. 资源科学, 2011, 33(2) : 223-229.]

[34] Liu HL, Dai GF, Zhang W et al. Analysis of the water ecological environment changes of the large lakes and driving factors in Lake Poyang basin: A case study of Lake Zhelin. J Lake Sci, 2015, 27(2) : 266-274. DOI: 10.18307/2015.0210. [刘 慧丽, 戴国飞, 张伟等. 鄱阳湖流域大型湖库水生生态环境变化及驱动力分析一一柘林湖为例. 湖泊科学, $2015,27(2): 266-274$.

[35] Li ZF, Yang GS. Research on non-point source pollution in Taihu Lake region. J Lake Sci, 2004, 16(suppl.) : 83-88. DOI: 10.18307/2004.sup11. [李兆富, 杨桂山. 太湖流域非点源污染特征与控制. 湖泊科学, 2004, 16 (增刊): 83-88.]

[36] Li YX, Hu YH, Wang YH et al. Wetland restoration and its purification efficiency in estuary of Dajie River, Lake Xingyun, Yunnan Province. J Lake Sci, 2007, 19(3) : 283-288. DOI: 10.18307/2007.0309. [李荫丞, 胡耀辉, 王云 华等. 云南星云湖大街河口湖滨湿地修复及净化效果. 湖泊科学, 2007, 19(3): 283-288.]

[37] Yang LZ, Wang DJ, Xia LZ. Features and ways of control of non-point agricultural pollution in Taihu area. China Water Resources, 2004, (20): 29-30. [杨林章, 王德建, 夏立忠. 太湖地区农业面源污染特征及控制途径. 中国水利, $2004,(20): 29-30$. ]

[38 Cheng B, Zhang Z, Chen L et al. Eutrophication of Taihu Lake and pollution from agricultural non-point sources in Lake Taihu Basin. Journal of Agro-Environment Science, 2005, 24(S1): 118-124. [程波, 张泽, 陈凌等. 太湖水体富营养 化与流域农业面源污染的控制. 农业环境科学学报, 2005, 24(S1): 118-124.]

[39] Quan WM, Yan LJ. Effects of agricultural non-point source pollution on eutrophication of water body and its control measure. Acta Ecologica Sinica, 2002, 22(3) : 291-299. [ 全为民, 严力蛟. 农业面源污染对水体富营养化的影响及其防 治措施. 生态学报, 2002, 22(3): 291-299.] 